\title{
Differentially expressed proteins in the human esophageal cancer cell line Eca-109, in the presence and absence of gemcitabine
}

\author{
ZENGHUANG $\mathrm{MA}^{1^{*}}$ and XIAOJIE XUE $\mathrm{X}^{2,3^{*}}$ \\ ${ }^{1}$ Huangshi Center for Clinical Laboratory; ${ }^{2}$ Department of Clinical Laboratory, Huangshi Central \\ Hospital of Edong Healthcare Group, Hubei Polytechnic University; ${ }^{3}$ Hubei Key Laboratory of \\ Kidney Disease Pathogenesis and Intervention, Huangshi, Hubei 435000, P.R. China
}

Received November 18, 2016; Accepted September 26, 2017

DOI: $10.3892 / \mathrm{mmr} .2017 .8041$

\begin{abstract}
The present study aimed to screen and study the roles of differentially expressed proteins in the human esophageal cancer cell line Eca-109, in the presence and absence of gemcitabine (GEM). The 3-(4,5)-dimethylthiahiazo (-z-y1)-3,5-di-phenytetrazoliumromide (MTT) method was used to assay the vitality of the Eca-109 cells following treatment with GEM (1-16 $\mu \mathrm{g} / \mathrm{ml})$. The cell apoptosis was measured by using fluorescence activated cell sorting. The proteins in the treated Eca-109 cells were extracted, validated, and assayed via two-dimensional gel electrophoresis combined with matrix-assisted laser desorption/ionization time of flight mass spectrometry (MALDI-TOF-MS). The differentially expressed proteins were then determined by western blotting. Furthermore, alterations in mitochondrial ultrastructure of the treated cells were observed under a transmission electron microscope. GEM significantly inhibited the growth of the Eca-109 cells in a concentration- and time-dependent manner, and the $50 \%$ inhibition concentration $\left(\mathrm{IC}_{50}\right)$ value was $3.87 \mu \mathrm{g} / \mathrm{ml}$. The MALDI-TOF-MS analysis revealed that there were three differentially expressed proteins following the GEM treatment, compared with the control. The differential proteins were verified to be B cell lymphoma-2 associated X, apoptosis regulator (Bax)- $\alpha$, apoptosis-associated speck-like protein containing a CARD (ASC) and myeloid cell leukemia sequence $(\mathrm{Mcl})-1$. Western blotting revealed that the expression levels of ASC and Bax- $\alpha$ proteins in the treated cancer cells were significantly upregulated, whereas the Mcl-1
\end{abstract}

Correspondence to: Dr Xiaojie Xue, Department of Clinical Laboratory, Huangshi Central Hospital of Edong Healthcare Group, Hubei Polytechnic University, 141 Tianjin Road, Huangshi, Hubei 435000, P.R. China

E-mail: xx_jie@126.com

*Contributed equally

Key words: gemcitabine, esophageal cancer, differential proteins, western blotting, matrix-assisted laser desorption/ionization time of flight mass spectrometry protein expression was markedly downregulated compared with the control. Furthermore, the GEM treatment destroyed the mitochondrial ultrastructure of the cancer cells, leaving swelled mitochondria, a fading matrix and destroyed the mitochondrial cristae. GEM significantly inhibits the growth and promotes apoptosis of the Eca-109 cells, due to the alterations in the expression levels of the differential proteins, including ASC, Mcl-1 and Bax- $\alpha$.

\section{Introduction}

The dynamic balance between cell proliferation and apoptosis is of importance in the maintenance of homeostasis (1-3). Once the balance is destroyed, cell apoptosis occurs, resulting in secondary damage. It has been verified that various genes are associated with cell apoptosis (4). B cell lymphoma (Bcl)-2 associated $\mathrm{X}$, apoptosis regulator (Bax) (5), p53 (6,7), and Fas $(8,9)$ promote cell apoptosis, whereas Bcl-2 $(5,10)$ and MYC Proto-Oncogene, BHLH Transcription Factor (myc) (11-13) inhibit cell apoptosis.

It has previously been demonstrated that tumor resistance to chemotherapy is closely associated with inactivation of apoptotic pathways (14-16). Therefore, a better understanding of the molecular mechanisms underlying tumor resistance is helpful to predict responses to drugs and assist in the design of tailored therapeutic regimens to overcome drug resistance.

Apoptosis is a well-organized process of programmed cell death. It may be initiated either by activation of death receptors on the cell surface membranes (extrinsic pathway) (17) or through a series of cellular events primarily processed in the mitochondria (intrinsic pathway) (18).

Previous studies have demonstrated that cell apoptosis is important to tumorigenesis (19-21). Defects in cell apoptosis result in a population expansion of neoplastic cells. Chemotherapy or radiotherapy-induced tumor cell death is largely mediated by the activation of apoptosis, and the inhibition of apoptosis enables the tumor cells to become resistant to these treatments.

In the present study, the inhibitory effects of gemcitabine (GEM), a commonly used therapeutic reagent in clinic, on the proliferation and induction of apoptosis of the human esophageal cancer cell line Eca-109, were assayed. Furthermore, the morphological alterations in the treated cancer cells were 
observed under a transmission electron microscope (TEM). Two-dimensional gel electrophoresis (2-DE), combined with matrix-assisted laser desorption/ionization time of flight mass spectrometry (MALDI-TOF-MS) were used to validate the differentially expressed proteins in the treated and non-treated Eca-109 cells. Western blotting was then used to quantify the differential proteins in the treated cancer cells. The present study therefore aimed to clarify the primary targets of GEM in the Eca-109 cells.

\section{Materials and methods}

Cell line and culture conditions. Human esophageal cancer cell line Eca-109 was provided by the Cell Resource Center of Shanghai Life Sciences Institute, Chinese Academy of Sciences (Shanghai, China). The cells were cultured in Roswell Park Memorial Institute (RPMI)-1640 medium (Thermo Fisher Scientific, Inc., Waltham, MA, USA), supplemented with $10 \%$ fetal bovine serum (Zhejiang Kangchen Biotech Co., Ltd., Wuhan, China), at $37^{\circ} \mathrm{C}$ in an atmosphere containing $5 \% \mathrm{CO}_{2}$. When the cells reached a confluence of $\sim 90 \%$ ( every three days), they were digested and passaged. The cells in passages 3-5 were used for experimental analyses.

MTT assay. The Eca-109 cells in logarithmic phase were prepared to a single cell suspension $\left(2 \times 10^{4} / \mathrm{ml}\right)$ and $100 \mu \mathrm{l}$ of the cells were added in 96-well culture plates. Then, $50 \mu \mathrm{l}$ of GEM ( $\geq 98 \%$, high performance liquid chromatography; Sigma-Aldrich; Merck KGaA, Darmstadt, Germany) was added in the wells to reach various final concentrations $(1,2,4,8,16 \mu \mathrm{g} / \mathrm{ml})$. Next, the treated cells were cultured in an atmosphere containing $5 \% \mathrm{CO}_{2}$ at $37^{\circ} \mathrm{C}$ for 24 or $48 \mathrm{~h}$. Following this, the cells were collected and centrifuged at $(150 \mathrm{x} \mathrm{g})$ for $10 \mathrm{~min}$. The supernatant was discarded, and the precipitate was washed with PBS once. A total of $200 \mu \mathrm{l}$ of serum-free RPMI-1640 medium was added, followed by addition of $10 \mu \mathrm{l}$ of MTT $(5 \mathrm{mg} / \mathrm{ml})$. Following culturing for a further $4 \mathrm{~h}, 100 \mu \mathrm{l}$ of dimethyl sulfoxide solution was added to dissolve the formazan. The cell viability was assessed by measuring the optical density (OD) at a wavelength of $450 \mathrm{~nm}$ in a Multiskan SPECTRUM full spectrum microplate spectrophotometer (Thermo Fisher Scientific, Inc., Waltham, MA, USA). The untreated wells also served as a control. Data from triplicate samples were averaged. The cell inhibition rate $=\left(\mathrm{OD}_{\text {control }}-\mathrm{OD}_{\text {treated }}\right) / \mathrm{OD}_{\text {control }} \times 100 \%$.

Analysis of cell apoptosis. The cells were seeded at a concentration of $2 \times 10^{4}$ cells $/ \mathrm{ml}$, then cells were treated with GEM $(4 \mu \mathrm{g} / \mathrm{ml})$. After co-cultured for 12 and $24 \mathrm{~h}$, the cells were removed from the plates by using $0.25 \%$ trypsin. The cells were centrifuged at $150 \mathrm{xg}$ for $10 \mathrm{~min}$ and then collected. Following washing with PBS twice, $1 \times 10^{5}-5 \times 10^{5}$ cells were resuspended in $500 \mu 1$ binding buffer and sequentially mixed with $5 \mu 1$ of Annexin V-FITC (Nanjing KeyGEN Biotech Co., Ltd., Nanjing, China) in the dark for $15 \mathrm{~min}$ at room temperature, followed by $5 \mu \mathrm{l}$ of propidium iodide (PI) (Nanjing KeyGen Biotech Co., Ltd., Nanjing, China) for $5 \mathrm{~min}$. The cells were incubated at room temperature in the dark for 5-10 min. Apoptotic cells were detected using a flow cytometer (Beckman Coulter, Inc., Brea, CA, USA) with an excitation wavelength at $488 \mathrm{~nm}$ and an emission wavelength at $530 \mathrm{~nm}$ and observed using a fluorescence microscope (Olympus Corporation, Tokyo, Japan). The data was analyzed using kaluza version 1.20 software (Beckman Coulter, Inc.).

Terminal deoxynucleotidyl-transferase-mediated dUTP nick-end labeling (TUNEL) assay. The treated cells were seeded in 24 -well plates $\left(2 \times 10^{5} / \mathrm{ml}\right)$. Following a culture period of $72 \mathrm{~h}$, the cells were fixed using $3.7 \%$ neutral formalin for $10 \mathrm{~min}$ at room temperature. Then, they were rehydrated with a descending gradient of ethanol $(100,95$, and $70 \%, 5 \mathrm{~min}$ each). Then, they were washed with PBS for $10 \mathrm{~min}$, and $50 \mu \mathrm{l}$ of cell suspension was added on a poly-1-lysine-pretreated slide. A total of $0.01 \mathrm{M}$ PBS was then used to wash the cells, followed by the TdT labeling at room temperature for $5 \mathrm{~min}$. The reaction was stopped with a stop buffer at room temperature for $5 \mathrm{~min}$, followed by an incubation with $50 \mu 1$ of FITC-labeled antibody (cat.: 129-10684; R\&D Systems Inc., Minneapolis, MN, USA) at room temperature for $30 \mathrm{~min}$, and then washed with PBS twice. The cell nuclei were examined under a laser scanning confocal microscope (at $490 \mathrm{~nm}$ excitation wavelength and $520 \mathrm{~nm}$ emission wavelength). A total of 20 random fields of view were selected for analysis.

Morphology assay of treated Eca-109 cells. The cells were treated with GEM $(8 \mu \mathrm{g} / \mathrm{ml})$ as previously described. Then, the cells were collected and prepared into specimens $\sim 3.0 \times 1.0 \mathrm{~mm}$, and then fixed in 3\% glutaraldehyde and osmic acid for $24 \mathrm{~h}$ at $4^{\circ} \mathrm{C}$. These specimens were dehydrated using graded ethanol at $37^{\circ} \mathrm{C}$ for $30 \mathrm{~min}$, followed by embedding in epoxy resin. Then, the specimens were cut into $50 \mathrm{~nm}$-thick sections consecutively. They were doubly stained with $2 \%$ uranyl acetate and lead citrate for $12 \mathrm{~h}$ at room temperature. The sections were washed and then the alterations in endocardium, nucleus, cytoplasm, and matrix components were examined using a HT7700 transmission electron microscope (Hitachi, Ltd., Tokyo, Japan).

Two-dimensional electrophoresis (2-DE) assay of differentially expressed proteins in the Eca-109 cells. The cells were treated as previously described. Following a culture period of $24 \mathrm{~h}$, the cells were harvested and collected. Then, a cell lysis solution was added containing $8 \mathrm{~mol} / \mathrm{l}$ urea, $40 \mathrm{~g} / \mathrm{l}$ CHAPS, $2 \mathrm{mmol} / \mathrm{l} \mathrm{TBP}$, and $2 \mathrm{ml} / \mathrm{l}$ Bio-Lyte. The cell lysates were collected and centrifuged at $13,400 \mathrm{x} \mathrm{g}$ at $4^{\circ} \mathrm{C}$ for $15 \mathrm{~min}$. The supernatant was then harvested and the proteins were quantified using the Bradford method.

The protein samples $(\sim 400 \mu \mathrm{g})$ were subjected to immobilized $\mathrm{pH}$ gradients (IPG) isoelectric focusing (IEF) and then run on sodium dodecyl sulfate polyacrylamide gel electrophoresis (SDS-PAGE). Next, the proteins were isolated by vertical electrophoresis. The gel was stained with coomassie brilliant blue R-250 for $2 \mathrm{~h}$ and destained for $2 \mathrm{~h}$ until the protein spots were clear. The stained proteins were scanned using a FXMolecular Imager (Bio-Rad Laboratories Inc., Hercules, CA, USA).

The differential protein spots (>than 3 -fold alteration in OD) were cut off from the gel and digested with $0.25 \%$ trypsin for $20 \mathrm{~h}$. The digested peptide fragments were isolated and 
desalinated with ZipTipTM (EMD Millipore, Billerica, MA, USA). Amino acid sequence analysis was then performed. According to the mass of the digested peptide fragment, the Mascot score was automatically obtained to verify the potential characteristics and names of the differential proteins by checking the Swiss-Prot protein database.

Western blotting of the differential proteins. The cells were treated and lysed using the aforementioned procedure. The proteins were separated by $12 \%$ SDS-PAGE and then transferred onto a sheet of polyvinylidene fluoride membrane. Following blocking with 5\% skim milk for $4 \mathrm{~h}$ and washing with Tris-buffered saline (TBS x3, 5 min), the membrane was respectively incubated overnight with anti-human ASC (cat no. sc-33958), Mcl-1(cat no. sc-53951) and Bax-a (cat no. sc-70408) polyclonal antibody (1:200; Santa Cruz Biotechnology, Inc., Dallas, TX, USA) at $4^{\circ} \mathrm{C}$, followed by incubation with horseradish peroxidase-conjugated rabbit anti-goat IgG (cat no. TA130028; 1:3,000; Origene technologies Inc., Beijing, China) for $2 \mathrm{~h}$ at room temperature. Immunoreactive bands were detected by an enhanced chemiluminescence reagent (Pierce; Thermo Fisher Scientific, Inc.), visualized by autoradiography, and quantified by the QuantityOne analysis system (Bio-Rad Laboratories, Inc.). $\beta$-actin (primary antibody dilution 1:200; cat no. sc-130656; Santa Cruz Biotechnology, Inc.) served as an internal control.

Statistical analysis. Data are expressed as the mean \pm standard error of the mean, and statistical comparisons were carried out by Student's t-test or one-way analysis of variance followed by Tukey's post hoc test, with the SPSS statistical software, version 17.0 (SPSS Inc., Chicago, IL, USA). $\mathrm{P}<0.05$ was considered to indicate a statistically significant difference.

\section{Results}

GEM inhibits proliferation of Eca-109 cells. The MTT results demonstrated that GEM significantly inhibited the proliferation of Eca-109 cells. Furthermore, the inhibitory effect was observed to have been exhibited in a time- and concentration-dependent manner. The greatest inhibitory effect of GEM was at $8 \mu \mathrm{g} / \mathrm{ml}$ for $24 \mathrm{~h}$ (Fig. 1).

GEM induces apoptosis of Eca-109 cells. Following treatment with GEM $(4 \mu \mathrm{g} / \mathrm{ml})$ for $12 \mathrm{~h}$, the apoptosis proportion (the cells doubly stained with AnnexinV-FITC and PI represent apoptotic cells) of the cancer cells significantly increased compared with the control $(17.5 \pm 5.1 \%$ vs. $8.1 \pm 2.4 \%, \mathrm{P}<0.05$; Fig. $2 \mathrm{~A}$ and $\mathrm{B}$ ). With the prolongation of the treatment time, the apoptosis proportion was significantly elevated in the treated cancer cells. The FACS result demonstrated that the apoptosis proportion in the GEM-treated cells was increased compared with controls $(36.1 \pm 8.8 \%$ vs. $16.4 \pm 5.8 \%, \mathrm{P}<0.01$; Fig. 2C and D).

Furthermore, TUNEL combined with laser scanning confocal microscope observations, demonstrated that GEM $(4 \mu \mathrm{g} / \mathrm{ml})$ significantly induced the apoptosis of the cancer cells. The majority of control cells were only stained with

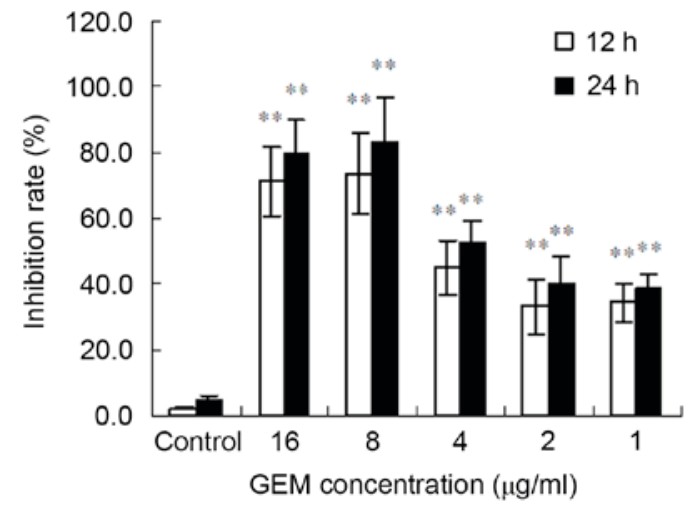

Figure 1. Growth inhibitory effect of GEM. Growth inhibition effect on the Eca-109 cells treated with GEM at various time points and at different concentrations. Data are expressed as the mean $(n=3) \pm$ standard error of the mean. ${ }^{* *} \mathrm{P}<0.01$ vs. control. GEM, gemcitabine.

PI and few with green fluorescence (Fig. 3A), whereas the apoptotic cells (AnnexinV-FITC and PI double staining) were stained with green fluorescence (Fig. 3B). In addition, nuclear staining density of the untreated cells was lower and the nuclear shapes were larger (Fig. 3A), whereas the treated cells had dense chromatins and comparatively smaller nuclear shapes (Fig. 3B).

The alterations in the mitochondrial ultrastructure of the treated Eca-109 cells were notable (Fig. 4). Following treatment with GEM for $24 \mathrm{~h}$, swelling mitochondria, fading matrix and a lack of mitochondrial crista were observed in the Eca-109 cells (Fig. 4).

Assay of the differential proteins in Eca-109 cells. The 2-DE assay result demonstrated that there were 12 protein spots between the acidic region ( $\mathrm{pH}$ 4.7-6.5). These protein spots were cut off and digested with trypsin (Fig. 5). The MALDI-TOF-MS assay was performed in the 12 protein spots to gain access to peptide fingerprints and charge to mass ratio. Then, three differentially expressed proteins including spots 3, 7 and 12 (Fig. 5) were identified by Mascot and a ProteinProspector peptide fingerprint matching software. The three differential proteins were validated to be Bax- $\alpha$ (spot 3), myeloid cell leukemia sequence (Mcl-1; spot 7), and apoptosis-associated speck-like protein containing a CARD (ASC) (spot 12). The gray scales were increased in Bax- $\alpha$ and ASC and decreased in Mcl-1 in the treated cells compared with the controls $(\mathrm{P}<0.01$; Fig. 6$)$.

GEM upregulates Bax- $\alpha$ and ASC and downregulates Mcl-1 expression levels in Eca-109 cells. The western blotting result demonstrated that Bax- $\alpha$ and ASC protein levels increased in the treated cells at 12 and $24 \mathrm{~h}$ following the GEM treatment (Fig. 7). However, the Mcl-1 protein levels in the treated cells significantly decreased compared with the control (Fig. 7)

\section{Discussion}

Esophageal carcinoma is one of the most frequently occurring cancers worldwide. According to the data from World Cancer Research Fund, the incidence of esophageal cancer is 

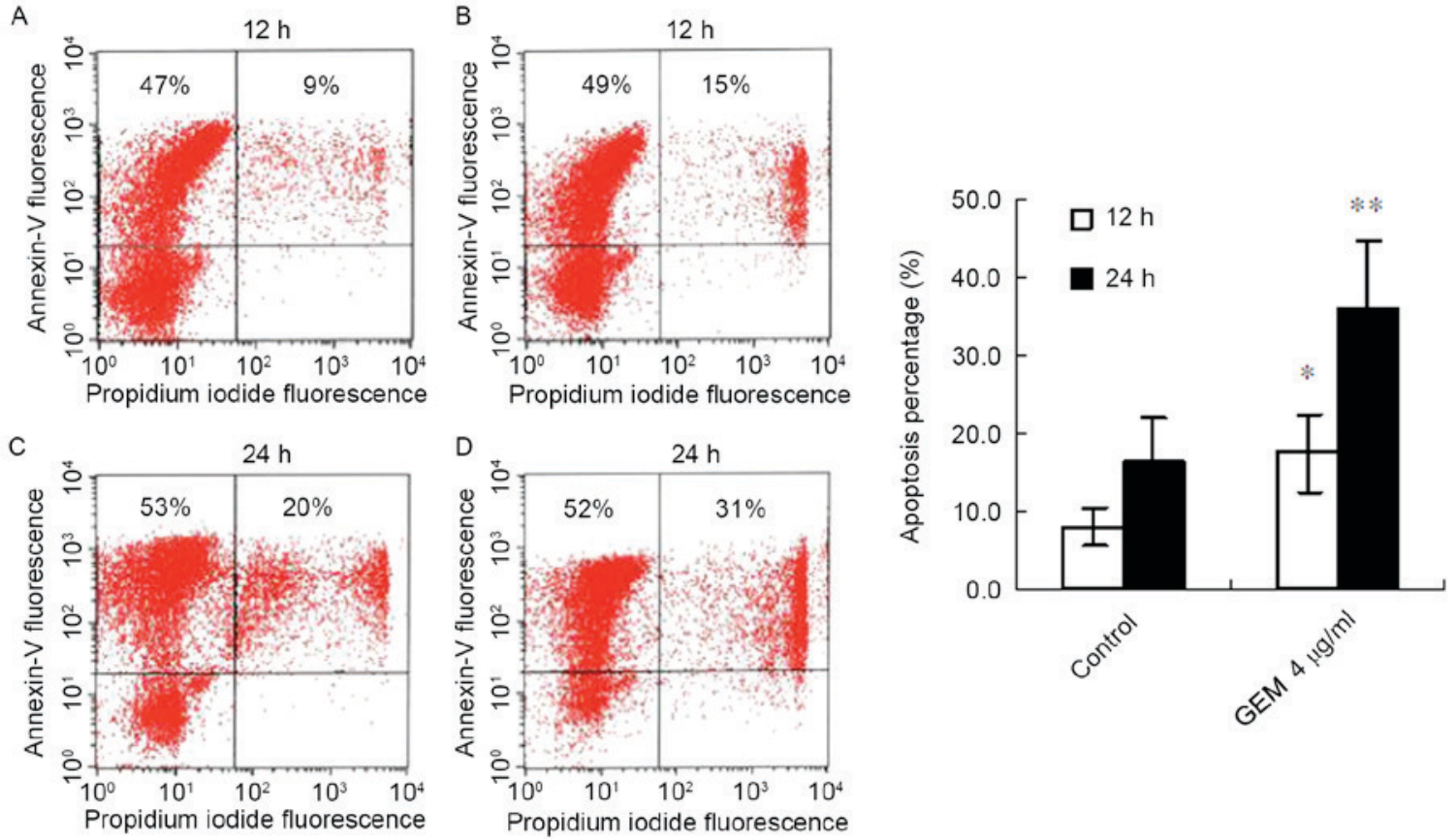

Figure 2. Apoptotic effect of GEM. Apoptosis assay of the Eca-109 cells treated with GEM for 12 or $24 \mathrm{~h}$. Data are expressed as the mean $(n=3) \pm$ standard error of the mean. (A) Eca-109 (12 h), (B) Eca-109 + GEM (12 h), (C) Eca-109 (24 h), (D) Eca-109 + GEM (24 h). ${ }^{*}$ P $<0.05,{ }^{* * *} \mathrm{P}<0.01$ vs. control. GEM, gemcitabine.

A

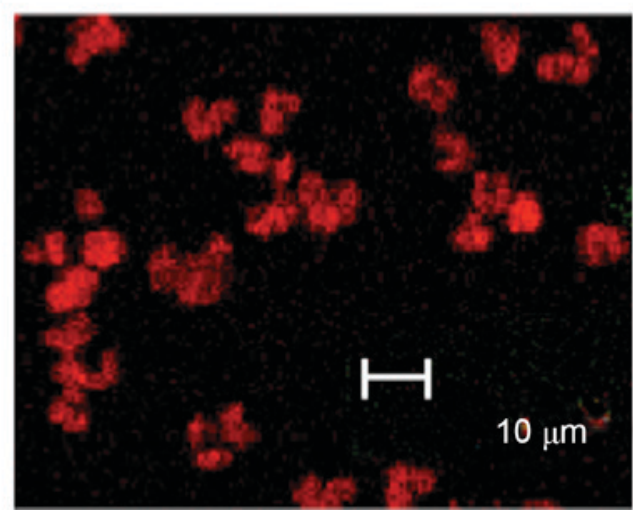

B

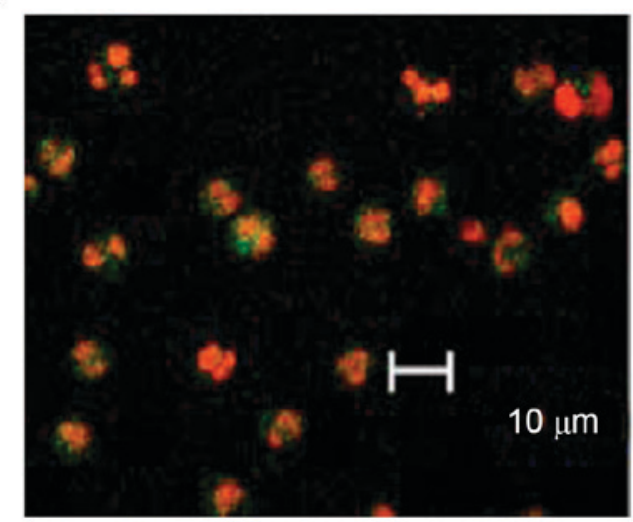

Figure 3. Alterations in the nuclei of the Eca-109 cells treated with GEM. (A) Eca-109 alone (24 h), (B) Eca-109 + GEM (24 h). The majority of control cells in (A) were only stained with PI and few with green fluorescence. The apoptotic cells in (B) with AnnexinV-FITC and PI double staining, were stained with green fluorescence (Scale bar=10 $\mu \mathrm{m}$ ). GEM, gemcitabine; PI, propidium iodide.

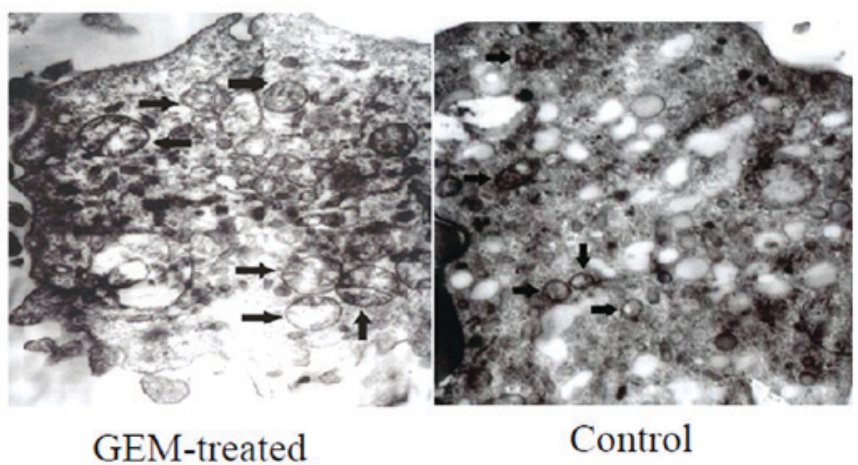

Figure 4. Ultrastructural alterations in mitochondria (x10,000 magnification) The Eca-109 cells exhibited alterations in mitochondrial structure following treatment with GEM for $24 \mathrm{~h}$. The swelling mitochondria, fading matrix and a destroyed and even disappeared mitochondrial cristae could be observed in the treated Eca-109 cells. GEM, gemcitabine. the seventh greatest cause of mortality in the world and the survival rate is low.

Chemotherapy is one of the palliative methods for the treatment of esophageal cancer. GEM, a deoxycytidine antitumor drug, has previously been demonstrated to exhibit anti-tumor properties against solid tumors (22-24). However, tumor resistance to GEM is becoming a primary issue of concern affecting chemotherapy. Studies on genesis in the development and prognosis of esophageal cancer provided certain evidence for the association between chemotherapeutic sensitivity and molecular targets $(25,26)$.

The results of the present study demonstrated that GEM inhibited the proliferation of the esophageal cancer cells in a time-and concentration-dependent manner. In other tumors, Toyota et al (27) demonstrated that GEM inhibited cell cycle progression in HuCCT-1 cells from $\mathrm{G}_{0} / \mathrm{G}_{1}$ to $\mathrm{S}$ phase, which 
A

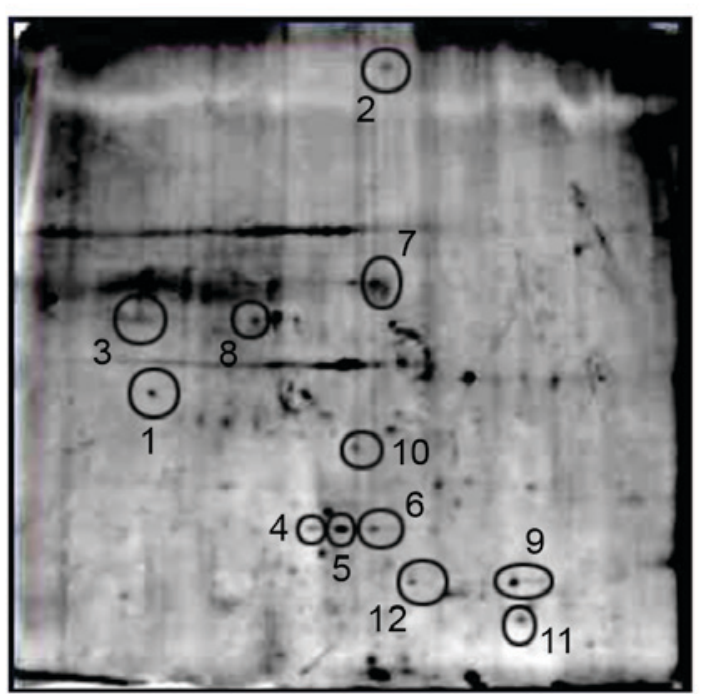

B

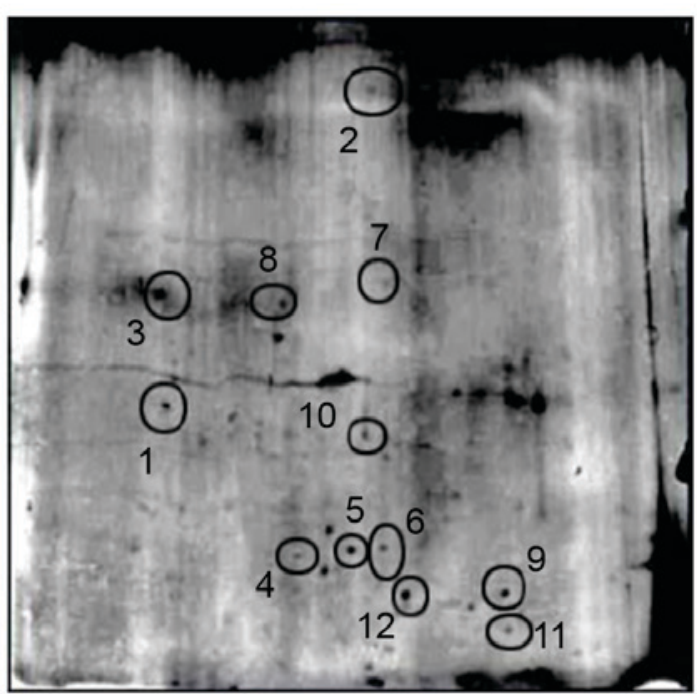

Figure 5. 2-DE patterns of protein spots. Treated or untreated cells with GEM were assessed using a 2-DE assay to identify protein spots. The individual circles in the image represent 12 protein spots between the acidic region of $\mathrm{pH} 4.7-6.5$. (A) 2-DE assay of protein spots in the untreated Eca-109 cells. (B) 2-DE assay of protein spots in the Eca-109 cells treated with GEM. GEM, gemcitabine.

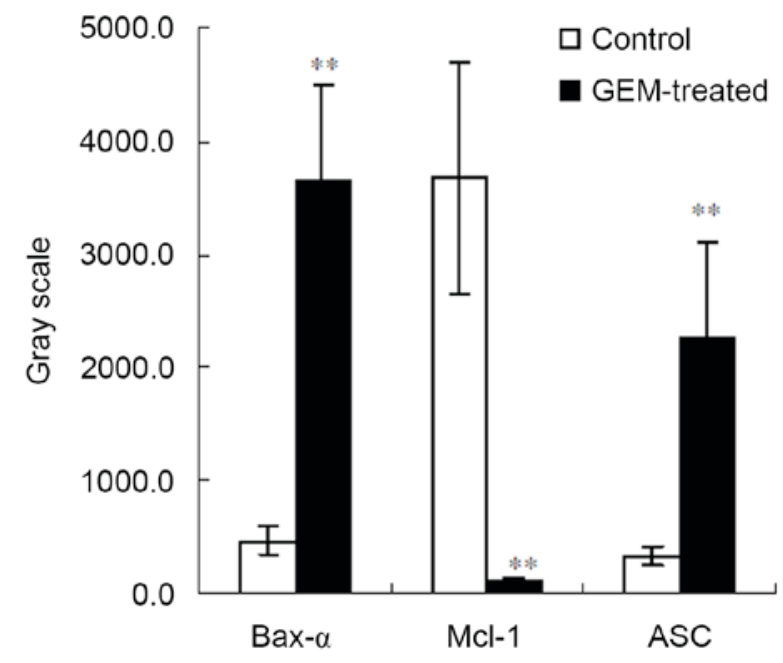

Figure 6. Grey scale results of differential proteins. Alterations in gray scale of Bax- $\alpha$, Mcl-1, and ASC proteins in the Eca-109 cells in the presence or absence of GEM. Data are expressed as the mean $(n=3) \pm$ standard error of the mean. ${ }^{* *} \mathrm{P}<0.01$ vs. control. GEM, gemcitabine; Bax- $\alpha$, B cell lymphoma- 2 associated $\mathrm{X}$, apoptosis regulator; ASC, apoptosis-associated speck-like protein containing a CARD; Mcl-1, myeloid cell leukemia sequence.

resulted in $\mathrm{G}_{1}$ cell cycle arrest for decreased expression of cyclin D1.

In addition, a study revealed that the level of ribonucleotide reductase subunit M1 (RRM1) is correlated with the therapeutic sensitivity to GEM. Cancer cells expressing a lower RRM1 level are more sensitive to GEM (28). The present study indicated that GEM significantly induced cell apoptosis, and this was supported by the TEM result. Following this, 2-DE combined with MALDI-TOF-MS was used to assay the differentially expressed proteins in the treated and untreated Eca-109 cells. Results demonstrated that there were three differentially expressed proteins including Bax- $\alpha, \mathrm{Mcl}-1$ and ASC in the treated Eca-109 cells compared with controls.

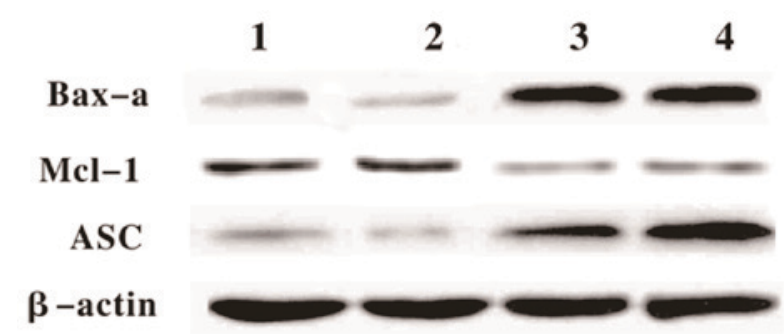

Figure 7. Differential protein expression levels in treated and untreated cells. Western blotting analyses of Bax- $\alpha$, ASC, and Mcl-1 protein expression levels in the Eca-109 cells. Lane 1, Eca-109 untreated (12 h); Lane 2, Eca-109 untreated (24 h); Lane 3, Eca-109 + GEM (12 h); Lane 4, Eca-109 + GEM (24 h). GEM, gemcitabine Bax- $\alpha$, B cell lymphoma- 2 associated $X$, apoptosis regulator; ASC, apoptosis-associated speck-like protein containing a CARD; Mcl-1, myeloid cell leukemia sequence.

The Bcl-2 family is a group of apoptosis-associated genes, which have an important role in inhibiting or promoting cell apoptosis. Bax- $\alpha$ and Mcl-1 are important members of the Bcl-2 family. It has previously been demonstrated that Mcl-1 exhibits an inhibitory role, and Bax- $\alpha$ exhibits the opposite effect in apoptosis. In the present study, the western blotting results revealed that GEM significantly upregulated ASC and Bax- $\alpha$ protein expression levels. As a receptor of Bax, ASC exhibits its role via the p53-Bax mitochondrial apoptotic pathway (29). ASC is a connexin containing caspase recruitment domain, termed CARD, and contains a pyrin domain, termed PYD. It is located on human chromosome 16p11.2-12. The CARD and PYD belong to the death domain family and exhibit key roles in cell apoptosis, inflammation, mediated immunity and tumor formation $(30,31)$.

In conclusion, the results of the present study demonstrated that GEM inhibited the growth and promoted the apoptosis of the Eca-109 cells. The alterations in the levels of various differentially expressed proteins, including ASC, Mcl-1 and Bax- $\alpha$, were responsible for this effect. 


\section{References}

1. Schutte B and Ramaekers FC: Molecular switches that govern the balance between proliferation and apoptosis. Prog Cell Cycle Res 4: 207-217, 2000.

2. Jaleco S, Swainson L, Dardalhon V, Burjanadze M, Kinet S and Taylor N: Homeostasis of naive and memory CD4+ T cells: IL-2 and IL-7 differentially regulate the balance between proliferation and Fas-mediated apoptosis. J Immunol 171: 61-68, 2003.

3. Mommers EC, van Diest PJ, Leonhart AM, Meijer CJ and Baak JP: Balance of cell proliferation and apoptosis in breast carcinogenesis. Breast Cancer Res Treat 58: 163-169, 1999.

4. Colitti M, Stefanon B and Wilde CJ: Apoptotic cell death, bax and bcl-2 expression during sheep mammary gland involution. Anat Histol Embryol 28: 257-264, 1999.

5. Heermeier K, Benedict M, Li M, Furth P, Nuñez G and Hennighausen L: Bax and Bcl-xs are induced at the onset of apoptosis in involuting mammary epithelial cells. Mech Dev 56: 197-207, 1996

6. Kastan MB, Canman CE and Leonard CJ: P53, cell cycle control and apoptosis: Implications for cancer. Cancer Metastasis Rev 14: 3-15, 1995.

7. Leonard CJ, Canman CE and Kastan MB: The role of p53 in cell-cycle control and apoptosis: Implications for cancer Important Adv Oncol 33-42, 1995.

8. Van Parijs L, Ibraghimov A and Abbas AK: The roles of costimulation and Fas in $\mathrm{T}$ cell apoptosis and peripheral tolerance. Immunity 4: 321-328, 1996.

9. Akiyama K, Chen C, Wang D, Xu X, Qu C, Yamaza T, Cai T, Chen W, Sun L and Shi S: Mesenchymal-stem-cell-induced immunoregulation involves FAS-ligand-/FAS-mediated T cell apoptosis. Cell Stem Cell 10: 544-555, 2012.

10. Schorr K, Li M, Krajewski S, Reed JC and Furth PA: Bcl-2 gene family and related proteins in mammary gland involution and breast cancer. J Mammary Gland Biol Neoplasia 4: 153-164, 1999.

11. Evan G, Harrington E, Fanidi A, Land H, Amati B and Bennett M: Integrated control of cell proliferation and cell death by the c-myc oncogene. Philos Trans R Soc Lond B Biol Sci 345: $269-275,1994$

12. Hoffman B and Liebermann DA: The proto-oncogene c-myc and apoptosis. Oncogene 17: 3351-3357, 1998.

13. Evan GI, Wyllie AH, Gilbert CS, Littlewood TD, Land H, Brooks M, Waters CM, Penn LZ and Hancock DC: Induction of apoptosis in fibroblasts by c-myc protein. Cell 69: 119-128, 1992.

14. Igney FH and Krammer PH: Immune escape of tumors: Apoptosis resistance and tumor counterattack. J Leukoc Biol 71 907-920, 2002

15. El Hage F, Abouzahr-Rifai S, Meslin F, Mami-Chouaib F and Chouaib S: Immune response and cancer. Bull Cancer 95: 57-67, 2008 (In French).

16. Zhao Y and Rangnekar VM: Apoptosis and tumor resistance conferred by Par-4. Cancer Biol Ther 7: 1867-1874, 2008.
17. Li J, Yu W, Tiwary R, Park SK, Xiong A, Sanders BG and Kline K: $\alpha$-TEA-induced death receptor dependent apoptosis involves activation of acid sphingomyelinase and elevated ceramide-enriched cell surface membranes. Cancer Cell Int 10: 40, 2010.

18. Olson M and Kornbluth S: Mitochondria in apoptosis and human disease. Curr Mol Med 1: 91-122, 2001.

19. Cappello F, Bellafiore M, Palma A and Bucchieri F: Defective apoptosis and tumorigenesis: Role of p53 mutation and Fas/FasL system dysregulation. Eur J Histochem 46: 199-208, 2002.

20. Ding HF and Fisher DE: Induction of apoptosis in cancer: New therapeutic opportunities. Ann Med 34: 451-469, 2002.

21. Pan G, Vickers SM,Pickens A, Phillips JO, Ying W, Thompson JA, Siegal GP and McDonald JM: Apoptosis and tumorigenesis in human cholangiocarcinoma cells. Involvement of Fas/APO-1 (CD95) and calmodulin. Am J Pathol 155: 193-203, 1999.

22. Fuxius S, Mross K, Mansouri K and Unger C: Gemcitabine and interferon-alpha 2b in solid tumors: A phase I study in patients with advanced or metastatic non-small cell lung, ovarian, pancreatic or renal cancer. Anticancer Drugs 13: 899-905, 2002.

23. Morisaki T, Hirano T, Koya N, Kiyota A, Tanaka H, Umebayashi M, Onishi $\mathrm{H}$ and Katano M: NKG2D-directed cytokine-activated killer lymphocyte therapy combined with gemcitabine for patients with chemoresistant metastatic solid tumors. Anticancer Res 34: 4529-4538, 2014.

24. Li Q, Yuan Z, Yan H, Wen Z, Zhang R and Cao B: Comparison of gemcitabine combined with targeted agent therapy versus gemcitabine monotherapy in the management of advanced pancreatic cancer. Clin Ther 36: 1054-1063, 2014.

25. Sanna V, Pala N and Sechi M: Targeted therapy using nanotechnology: Focus on cancer. Int J Nanomedicine 9: 467-483, 2014.

26. Xiao JY, Lee JY, Tokuhiro S, Nagataki M, Jarilla BR, Nomura H, Kim TI, Hong SJ and Agatsuma T: Molecular cloning and characterization of taurocyamine kinase from Clonorchis sinensis: A candidate chemotherapeutic target. PLoS Negl Trop Dis 7: e2548, 2013.

27. Toyota Y, Iwama H, Kato K, Tani J, Katsura A, Miyata M, Fujiwara S, Fujita K, Sakamoto T, Fujimori T, et al: Mechanism of gemcitabine-induced suppression of human cholangiocellular carcinoma cell growth. Int J Oncol 47: 1293-1302, 2015.

28. Luo $Y$, Lin $C$, Zhang $X Y$, Liang $X, F u ~ M$ and Feng FY: Relationship between the level of RRM1 expression and the sensitivity to gemcitabine in the esophageal squamous cell carcinoma cell lines. Zhonghua Zhong Liu Za Zhi 31: 660-663, 2009 (In Chinese).

29. Ohtsuka T, Ryu H, Minamishima YA, Macip S, Sagara J, Nakayama KI, Aaronson SA and Lee SW: ASC is a Bax adaptor and regulates the p53-Bax mitochondrial apoptosis pathway. Nat Cell Biol 6: 121-128, 2004.

30. Liu W, Luo Y, Dunn JH, Norris DA, Dinarello CA and Fujita M: Dual role of apoptosis-associated speck-like protein containing a CARD (ASC) in tumorigenesis of human melanoma. J Invest Dermatol 133: 518-527, 2013.

31. Proell M, Gerlic M, Mace PD, Reed JC and Riedl SJ: The CARD plays a critical role in ASC foci formation and inflammasome signalling. Biochem J 449: 613-621, 2013. 